DOI: 10.17805/ggz.2019.5.2

\title{
Русофобия в Прибалтике
}

\author{
А. Н. Ильин
}

Омский государственный педагогический университет

В статье доказывается несамостоятельный характер русофобского нарратива, исходящего от прибалтийских элит. Этот нарратив - одна из форм проявления политической покорности элитам США. Ухудшение отношений с Россией крайне невыгодны для стран Балтии, однако их зависимость от воли Вашингтона не позволяет им обратиться лицом к России. Русофобские обвинения не имеют доказательной базы, а нередко выступают показателем лицемерия обвиняющей стороны. Затронуты такие проблемы, как: риск российской агрессии по отношению к Восточной Европе, претензии к Советскому Союзу за оккупачию Прибалтики, симпатии балтийских элит к нацизму.

Ключевые слова: русофобия; Россия; Латвия; Литва; Эстония; Прибалтика

\section{Russophobia in the Baltic States \\ A. N. Ilyin \\ Omsk State Pedagogical University}

In this article, we prove a dependent character of the Russophobic narrative coming from the Baltic elites. This narrative is a form of political submission to the elites of the United States. The deterioration of relations with Russia is extremely disadvantageous for the Baltic states, but their dependence on the will of Washington does not allow them to face Russia. Russophobic accusations have no evidence base, and often act as an indicator of the hypocrisy of the accusing party. The following issues are considered: the risk of Russian aggression against Eastern Europe, claims to the Soviet Union for the occupation of the Baltic states, the sympathy of the Baltic elites to Nazism.

Keywords: Russophobia; Russia; Latvia; Lithuania; Estonia; Baltic states

\section{ВВЕДЕНИЕ}

Политика, экономика, идеология не терпят пустоты. Когда какая-либо ниша становится свободной, ее обязательно кто-то занимает. Когда некий субъект международной системы ослабляется, он переходит под контроль 
более сильного и теряет свою политическую субъектность. Таковы геополитические реалии.

После развала Советского Союза Россия и другие республики СССР попали под серьезный контроль со стороны США, ставших тогда самой сильной державой в мире. Для подавления своих противников она использует множество различных орудий: военное вмешательство, инициирование госпереворотов, подсаживание конкурентов на удочку кредитных долгов (чем занимаются Всемирный банк и Международный валютный фонд) и т. д. Наиболее сильный актор международных отношений пользуется своей силой, и это вполне закономерная ситуация.

В современном глобальном обществе спектакля стало не важно, говорят ли наиболее влиятельные в мире СМИ правду или ложь; все, что подается в качестве правды, таковой воспринимается. Поэтому одним из значимых видов воздействия на соперников является идеологическая индоктринация. Русофобия - форма ее проявления. Mbl четко разделяем русофобию и объективную критику, так как первая не имеет под собой серьезной обвинительной базы, не опирается на достоверные факты и доказательства. Русофобию нецелесообразно сводить исключительно к набору предрассудков, которые на уровне синергетической самоорганизации воспроизводят себя в общественном мнении различных народов. Русофобия - это одно из циничных средств ведения информационной войны против непокоренного народа.

Элиты мирового гегемона постоянно заявляют, что во многих проблемах современности виновны русские, а позволившие себя оккупировать американскими военными базами европейские государства вынуждены принимать данный дискурс, солидаризироваться с ним, обогащать его новыми сведениями и всячески тиражировать. Особенно в этом поднаторел восточноевропейский истеблишмент. Недаром С. Амин писал, что в странах Восточной Европы управляющие классы примкнули к американскому проекту грабежа мира, поскольку эти классы сформированы культурой подобострастия и раболепства (Амин, 2007). По той же причине они примкнули к проекту «Русофобия». На ум приходит поговорка, в соответствии с которой выстраивают свою политику прибалтийские (и в целом восточноевропейские) элиты: «Если ты не можешь победить сильного врага, надо к нему присоединиться». Только присоединение, мягко говоря, сулит совсем сомнительные выгоды.

Ряд стран Восточной Европы сделал русофобию чуть ли не национальной идеей, основой государственной политики. Несмотря на то, что в экономическом смысле эти страны исторически ориентированы на взаимодействие с Россией, они сознательно делают все для потери хороших отношений с РФ. Уйдя под контроль США и транснационального бизнеса, они обрекаются на нищету, деиндустриализацию и потерю государственного суверенитета - 
именно после открытия их экономик Штатами в ходе формирования зоны свободной торговли стали происходить эти катастрофические процессы. Для «цивилизованного» мира они - всего лишь полупериферии, полуколонии и рынки сбыта. Этот факт показали не теоретические построения аналитиков, а сама реальность жизни за последующие после крушения СССР десятилетия. Понимая это, восточноевропейские элиты все равно играют в чужую - антироссийскую - игру. Если бы они желали развития экономики своих стран, им пришлось бы уходить от русофобского дискурса и внешнего диктата и налаживать отношения с Россией. Получается, они предают интересы собственных народов, разменивая их благосостояние на личное обогащение и на прислуживание интересам мирового гегемона. Постоянным наращиванием антирусской риторики они в некотором роде демонтируют свои народы, «воспитывают» новые поколения, которые будут воинственно настроены по отношению к РФ, несмотря на то, что последняя никогда их не грабила и не эксплуатировала, в отличие от западного мира.

М. Г. Делягин приводит много сведений, указывающих на обеднение и деиндустриализацию стран Восточной Европы после их включения в орбиту американского влияния и интеграции в систему неолиберализма. Они захвачены глобальными корпорациями, которые решают их будущее в большей степени, чем национальные правительства. К их мнению не прислушиваются в «демократической» Европе. Делягин также приводит весьма интересные слова нобелевского лауреата, бывшего старшего вице-президента Всемирного банка Дж. Стиглица. Он заявил, что большинство споров в рамках ВТО между развитыми и неразвитыми странами «почему-то» выигрывают именно развитые (Делягин, 2015). Вот такой принцип равенства всех перед законом! Кроме того, Старый Свет отличается неравенством регионального развития, и его восточная часть наименее развита.

Остановимся более подробно на данных, взятых из книги «Новая Россия». Во всей Восточной Европе произошла массовая скупка активов, после которой корпорации Запада стали хозяевами как банковских систем, так и всей экономики. Судьбы стран стали определяться не национальными правительствами, а корпорациями старой Европы и решениями Еврокомиссии. Восточная Европа вместо суверенитета обрела колониальную зависимость. Вступление в Евросоюз обязало бывшие социалистические страны ограничить торговлю с Россией. В том числе потому, что высокотехнологичная продукция новых членов ЕС оказалась неконкурентоспособной на внутреннем рынке Европы, произошла деиндустриализация. В целом развитые страны не желали видеть в Восточной Европе конкурента, поэтому изъятием ее ресурсов сознательно снижали ее конкурентоспособность. Следовательно, вместо справедливого и равного сотрудничества приходится говорить о гра- 
беже и неоколониальной эксплуатации. При этом США продолжает оказывать влияние на решения ЕС, а элиты некоторых стран (Польша, Болгария, Латвия, Литва и Эстония) вообще представляют собой американских марионеток.

Внутриевропейская конкуренция вызвала в Восточной Европе массовую безработицу, утрату рабочей силой квалификации, вытеснение населения в нестабильные сектора с высоким уровнем самоэксплуатации (мелкая торговля, сельское хозяйство и т. д.). Из восточноевропейских стран усилилась миграция в развитые страны ЕС, где она негативно повлияла на рынок труда. Небольшое относительное улучшение экономических показателей восточноевропейских стран произошло из-за переноса туда экологически вредных производств. В Румынии, Болгарии и Прибалтике была организована промышленная катастрофа, вследствие которой квалифицированные работники побежали на Запад; в 2007-2008 гг. из Румынии уехало 20-30 \% экономически активного населения (2-3 млн человек). Это создало в данных странах дефицит рабочей силы и повысило стоимость оставшейся, что лишило эти страны преимущества дешевизны квалифицированного труда. Из-за закрытия производств подготовка специалистов почти закончилась.

Добавленная стоимость стала выводиться из Восточной Европы в страны базирования глобальных корпораций. Президент Чехии в 2003-2013 гг. В. Клаус признал, что вступление его страны в ЕС превратило ее в «объект выкачивания денег». Эта судьба постигла все страны Восточной Европы, сальдо текущих операций платежного баланса которых еще до начала кризиса 2008 г. было значительно хуже, чем в 1990 г. В Болгарии оно упало с 8,1\% ВВП в 1990 г. до -25,2 \% ВВП в 2007 г., в Чехии - с 0 до -4,4 \%, в Венгрии - c $+1,1 \%$ до -7,3 \%, в Польше - c $+4,9$ \% до -6,2 \%, в Румынии с -4,6 \% до -13,4 \%. За 1992--2007 гг. в Словении оно снизилось с $+5,7 \%$ до 4 \% ВВП, в Литве - c +5,3 \% до $-14,5 \%$, в Латвии - c $+12,3 \%$ до $-22,4 \%$. За 1993-2008 гг. в Эстонии оно упало с $+1,2 \%$ до -15,1 \% ВВП, в Словакии — c -4,9\% до -5,3\%. В 2014 г. в пяти странах Восточной Европы текущее сальдо платежного баланса стало лучше, чем в 1990 г. (в других пяти - попрежнему хуже): в Словении оно составило $+5,9 \%$ ВВП, в Венгрии $+2,5 \%$, в Словакии - +1,9\%, в Литве - +0,9\%, в Латвии - $-0,1 \%$, в Болгарии и Чехии - по -0,2 \%, в Румынии - $-1,2 \%$, в Польше - $-1,5 \%$, в Эстонии - $-2,2 \%$. Однако наверняка это «достижение» - результат законченности в странах финансовых ресурсов, которые из них можно вывести; такая законченность нормализует платежный баланс. Также примечательна история с выделением средств из фондов Евросоюза. Так, в 2007 г. Румыния могла получить из них 2 млрд евро, но в реальности смогла использовать только 400 млн евро из фонда рыболовства; тогда же ее взнос в бюджет ЕС составил 
1,1 млрд евро (1,8 \% ВВП), т. е. Румыния из бенефициара превратилась в донора ЕC.

М. Г. Делягин небезосновательно именует Евросоюз зоной, где крупный бизнес старой Европы получает прибыль за счет подавления любых конкурентов в присоединившихся к ЕС странах. Дезинтеграция ЕС корпоративному бизнесу приносит дополнительную прибыль. Так, наиболее развитые члены ЕС улучшают свою репутацию за счет ослабления других; в дело вступает контраст. Например, максимально возможный уровень потерь Германии на витке греческого кризиса оценивался в 90 млрд евро, но выигрыш Германии от роста стоимости ее ценных бумаг, в немалой части обусловленного ее превращением в тихую гавань Европы на фоне терпящей крах Греции, к середине 2015 г. принес ей около 100 млрд евро, т. е. перекрыл возможные убытки. Добавим, что евроинтеграция потребовала от Греции ограничить производство своих экспортных товаров (вино, табак, оливки, хлопок), которые не нужны внутреннему европейскому рынку, а греческое судостроение не выдержало глобальной конкуренции (Делягин, 2016).

Несмотря на все эти неутешительные результаты политической и экономической интеграции восточноевропейских стран в «цивилизованный» мир, они продолжают обвинять в ряде своих бед Россию. Часть антироссийских выпадов носит внутренний характер и является в основном результатом кривизны переосмысления ряда исторических событий, связывавших Россию и страны Балтии. Другая часть русофобских обвинений имеет внешнюю природу и к взаимодействию между РФ и Прибалтикой прямого отношения не имеют; недаром балтийские элиты солидаризировались со многими недоказанными обвинениями России, которые исходят из США или Великобритании. Т. е. в одном случае мы наблюдаем пустое фантазматическое повествование русофобствующей речи прибалтийского правящего класса, а в другом случае - не менее пустое фантазматическое повествование русофобствующих элит мирового гегемона, поддержанное прибалтийским истеблишменTOM.

\section{РОССИЯ АПРИОРИ АГРЕССИВНА}

«Демократический» Запад закрывает глаза на фашистские марши в странах Балтии и риторику, согласно которой воевавшие против СССР коллаборационисты являются героями. Запад не замечает дискриминации русских в Прибалтике и во многих других государствах: ограничения в приеме на работу, лишение возможности для экономической и культурной активности, физическое насилие, диффамация в массмедиа, наступление на русский язык, лишение русских людей гражданских прав. В Прибалтике объявили войну всему русскому, в том числе русским именам и фамилиям. Так, в Лат- 
вии пытаются «латвизировать» русские имена и фамилии. Пушкин превращается в Пискинса, а Шишкин — в Сискинса.

И когда российская власть начинает даже в самых мягких и половинчатых формах защищать их права, «цивилизованный» мир вместе с прибалтийскими элитами разражается риторикой о новых имперских поползновениях русских. Этих пропагандистов не смущает отсутствие доказательств, которые бы подтверждали такие стремления. Их не смущает то, что история России крайне бедна наступательными войнами, и потому нельзя сослаться на агрессивные традиции русских, соответствующие многовековой ментальности. Агрессором все равно выступает Россия, как бы США не терроризировали мир и не устраивали перевороты (в той же Украине), приводящие к бедам народа и десуверенизации страны-объекта действий Вашингтона.

Перед Днем Победы над фашизмом, 4 мая 2019 г. в Чикаго открыли памятник литовскому нацисту Адольфасу Раманаускасу, который являлся одним из лидеров «лесных братьев». Он также после нацистской оккупации Литвы руководил боевиками, охотившимися на евреев в Друскининкае. Затем участвовал в убийстве поляков, а после войны пополнил собой антисоветское подполье. В 1957 г. был казнен. В Литве его объявили невинным. Ранее литовская писательница Рута Ванагайте заявила, что к массовому истреблению евреев причастен Раманаускас. В ответ ее назвали чекисткой и агентом Кремля, издательство уничтожило тиражи ее книг, а книги, уже поступившие в продажу, подверглись изъятию (см.: Вассерман, 2019а: Электронный ресурс). Причем элиты соответствующих стран постоянно педалируют тему отсутствия демократии и свободы слова в России.

Глядя на происходящее, следует сделать выводы поистине глобального масштаба. Фашизм был абсолютным злом, которое в свое время полностью перечеркнуло общечеловеческие ценности, мораль, гуманизм, представления о должном, о социальной справедливости, достойном обществе и хорошей культуре. Сейчас возникли серьезные очаги преклонения перед этим исчадием, воплощенные в нацистских маршах Прибалтики и всей государственной политике Украины. Коллективный Запад склонен поддерживать преклонение перед абсолютным злом, как бы не замечая этого. Мы здесь видим проявляющиеся на масштабном (цивилизационном) уровне подвижки в сторону отхода от действительно общечеловеческих ценностей, нормальной морали и принципов гуманизма. Вопрос: что будет дальше? Ведь такое движение чревато в конечном счете полной, безоговорочной, официально принятой реабилитацией того, что было на мировом уровне признано абсолютным злом.

В конце 2014 г. президент Литвы Даля Грибаускайте охарактеризовала Россию как террористическое государство и заговорила о необходимости поддержки Украины, в том числе военными средствами. Но разговорами и 
призывами дело не закончилось, поскольку выяснилось, что Литва тогда же начала продавать Украине свою старую военную технику. Какие из этого можно сделать выводы? Во-первых, риторика Литвы ничем не отличается от риторики ее американских хозяев (а совсем не партнеров), и руководство страны уже не знает, какое еще раболепие проявить, чтобы услужить Вашингтону. Во-вторых, называющая себя демократичной страна (впрочем, как и остальные страны «цивилизованного» Запада) солидаризуется с антидемократическими процессами, происходящими на Украине. В незалежной убивают, избивают и всячески преследуют людей за их несогласие с официальной идеологией. Украинская армия расстреливает мирных жителей Донбасса. Сам государственный переворот был крайне насильственным, протестующие избивали и убивали сотрудников силовых структур. Но Литва вслед за всеми закрывшими на эти факты глаза «цивилизованными» странами повторяет риторику, совершенно противоречащую реальности. Демократия на словах, фашизм на деле. В-третьих, позиция Литвы в отношении Украины недвусмысленно демонстрирует позицию Литвы в отношении России, совсем не дружескую.

США потратили на украинскую революцию 2014 г. около \$5 млрд, о чем сказала В. Нуланд. Итальянский журналист Дж. Кьеза пишет, что нацистские «Правый сектор» и «Свобода» были заблаговременно созданы на деньги Запада; пожертвования внесли американцы, канадцы и поляки. Запад активно инвестировал в украинские СМИ и подчинял себе все значимые культурные учреждения страны. На территории Польши и Прибалтики находились тренировочные лагеря, в которых готовились украинские нацистские банды (Кьеза, 2016). После этого прибалтийские элиты продолжают говорить о своей приверженности демократическим ценностям и противопоставлять себя архаичной, варварской и далекой от демократичности России. Конечно, проблем, связанных с демократией, в России очень много - но вряд ли больше, чем в любой иной капиталистической стране.

Россия предельно мягко, даже беззубо, пытается противостоять притеснению русскоязычных жителей стран Балтии, вместо проявления агрессии всего лишь вяло протестуя. Это не похоже на империалистические устремления. Если бы правительства Прибалтики действительно боялись агрессивной России, вряд ли они позволили бы себе дискриминировать русскоязычное население. И непонятно, зачем России захватывать Прибалтику и Восточную Европу, если она их отпустила во время развала СССР?

Весьма показательна давняя история с Василием Кононовым, командиром отряда 1-й Латвийской партизанской бригады. Она одновременно демонстрирует фашистские симпатии латвийских властей и беззубость России вместо ее экспансионизма. В. Кононова преследовали довольно долго, с 
1998 г. было несколько судебных процессов. Его обвиняли в убийстве во время войны девятерых мирных жителей. В 2000 г. он был приговорен к 6 годам в тюрьме закрытого типа за геноцид и преступления против человечества. Причем его действия в указанный период не являлись уголовно наказуемыми, и этот факт снимает с него статус субъекта преступления. Признавать Кононова уголовно ответственным было недопустимо. Всеобщая декларация прав человека от 10 декабря 1948 г. утверждает: «Никто не может быть осужден за преступление на основании совершения какого-либо деяния или за бездействие, которые во время их совершения не составляли преступления по национальным законам или по международному праву». Латвия присоединилась к Декларации в 1993 г. Вынесенный вердикт — грубое нарушение Всеобщей декларации прав человека. Более того, отсутствие мотивировки в приговоре суда, который осудил Кононова за не являвшиеся в 1944 г. уголовно наказуемыми действия, выступает нарушением уголовного права. В. Путин удовлетворил обращение В. Кононова о предоставлении ему российского гражданства. В апреле 2000 г. Кононова освободили из-под стражи вследствие признания Верховным судом недоказанности предъявленных обвинений. Сразу же латвийская прокуратура направила его дело на повторное рассмотрение, которое началось в 2002 г. В октябре 2003 г. Латгальский окружной суд освободил подсудимого от ответственности в связи с истечением срока давности. Суд учел доводы защиты, в числе которых тот факт, что полицаев недопустимо квалифицировать как мирных жителей. Кононова признали виновным не в совершении военных преступлений, а в бандитизме, и с рядом оговорок. Генпрокуратура Латвии бросилась опротестовывать оправдательный приговор. В апреле 2004 г. Верховный суд Латвии приговорил В. Кононова к одному году и восьми месяцам тюрьмы за военные преступления, но в тюрьму подсудимый не попал, поскольку ранее по этому же делу он провел за решеткой аналогичный срок (Дело бывшего ... , 2011: Электронный ресурс; Соколова, 2000: Электронный ресурс). Однако процесс продолжился.

Дело Кононова - далеко не единственное. В Риге было объявлено о намерении правоохранительных органов продолжать преследовать в судебном порядке ветеранов войны. Тогда же в Латвии шел процесс над бывшим сотрудником НКВД и участником войны Евгением Савенко. Обвинения в «геноциде латышского народа» выдвигались в адрес бывших сотрудников правоохранительных органов и участников войны Ильи Машонкина, Николая Ларионова, Василия Кирсанова. Эти дела объединяет то, что обвинения данных людей в военных преступлениях или геноциде опираются на юридически несостоятельные, исторически и морально неприемлемые посылки, связанные с обелением фашизма и криминализацией борцов против него 
(Соколова, 2000: Электронный ресурс).

Члены Национал-большевистской партии М. Журкин, С. Соловей и Д. Гафаров в 2000 г. забаррикадировались на смотровой площадке Собора святого Петра в Риге, вывесили красные флаги и транспарант «Свободу нашим ветеранам!». Скандируя «Фашизм не пройдет!», они разбросали листовки с требованием освободить из тюрьмы ветеранов Советской Армии Кононова, Фарбуха и Савенко, которых осудили за борьбу с латвийскими фашистами в период Великой Отечественной войны. Также НБПэшники требовали равных гражданских прав для всех 900 тысяч «неграждан» Латвии и отказа от вхождения Латвии в НАТО. Эта акция была направлена против режима апартеида в Латвии и возрождения фашизма. За эту акцию Соловей, Журкин и Гафаров были осуждены как «террористы» на большие сроки заключения. Из материалов суда и из официального ответа заместителя Н. Патрушева В. Шульца на письмо депутата В. Алксниса стало известно, что ФСБ посоветовала латвийским структурам осудить организаторов акции не по статье «хулиганство» (как те планировали), а по статье «терроризм» (см.: Тарасов, 2003). Вот такая агрессивность России, которая пусть даже косвенным образом, но потакает профашистским действиям латвийских властей.

Позже дело Кононова пересматривалось. Латвия в 2010 г. вынесла обвинительный приговор. Большая палата Европейского суда по правам человека (ЕСПЧ) заявила, что Латвия не нарушила Европейскую конвенцию по правам человека, осудив красного партизана В. Кононова. Согласно ЕСПЧ, Латвия действовала юридически корректно. Большая палата ЕСПЧ признала вину В. Кононова в военных преступлениях, а МИД РФ осудил этот опасный прецедент (Мурниеце, 2010: Электронный ресурс). Соответствующие решения пролили свет на характер исторического видения латвийских и европейских властей. В них проглядывают политические интересы, на заклание которым отдается судьба борца против фашизма. Сами по себе эти решения являются профашистскими и антисоветскими, прокладывающими дорогу для реабилитации нацизма. Добавим, что вердикт глубоко оскорбляет жителей всех республик бывшего Советского Союза с их чувством справедливости и уважением к своим ветеранам, которые - как ни пересматривай историю войны - стояли на стороне добра. А может быть, к военным преступникам тогда следует приписать всех, кто участвовал в освобождении Латвии от фашизма, и назвать героями каждого, кто прислуживал фашизму? Именно на эту дорогу встали прибалтийские власти, официально провозглашающие, что СССР был захватчиком. Россия всего лишь осуждала происходящее, не прибегая к серьезным средствам давления.

В марте 2019 г. в Вильнюсе был инициирован судебный процесс над 
российскими офицерами за их участие в событиях 1991 г., когда начались в Литве бунты за независимость республики. Туда была отправлена группа военных, которые ни в кого не стреляли. Неизвестные снайперы-провокаторы открыли с крыши огонь, приведший к гибели людей, в том числе офицера группы «Альфа» (это типичная методика американцев, которые применяют ее в странах, где желают провести госпереворот). Снайперская стрельба не была расследована, до сих пор в деле существует много вопросов, как и в деле снайперов на киевском майдане 2014 г. Но в ряде стран, и Литва здесь не исключение, принято во всем обвинять Россию. Сегодня перед судом предстали российские военные за их борьбу против не существовавшей тогда государственности Литвы.

В апреле 2018 г. постоянно контактирующий с американскими чиновниками глава МИД Эстонии Свен Миксер в лучших традициях раболепия перед мировым гегемоном назвал Россию инициатором военного конфликта с Грузией в 2008 г. и на Украине в 2014 г. Видимо, в своем оголтелом конформизме перед Штатами он отстал от жизни, поскольку забыл простую общеизвестную истину: в 2008 г. все факты указали на грузинскую агрессию. Миксер также порекомендовал странам Запада вести диалог с РФ только с позиции силы и держаться единства, а учения НАТО у российских границ он именовал «способом сохранить мир» (Москва ответила ... , 2018: Электронный ресурс). До этого он призывал НАТО к усилению мер сдерживания России. Как говорится, оруэлловский новояз процветает. Агрессию НАТО и США связывают с миром, а российское миролюбие - с опасностью. Эти деятели говорят о важности мира и одновременно постулируют необходимость коммуницировать с Россией на языке силы. Именно Россия при общении с другими странами избегает ультимативного стиля, всегда ведет разговор содержательно и уважительно, без резких нападок. Странам «цивилизованного» мира свойственно общаются так, как будто оппонент им должен и обязан, причем никогда не объясняя, почему оппонент должен прогибаться под их ультиматумы.

Совещательный орган под названием «Балтийская ассамблея», в который входит по 20 депутатов парламентов Эстонии, Латвии и Литвы, в ноябре 2018 г. рекомендовала этим странам расширить оборонное сотрудничество и упростить передвижение армий союзников по воздуху, суше и морю, чтобы противостоять российским угрозам. Речь шла об инвестиции надежд в НАТО, который защитит от угроз, связанных с провокационными действиями вооруженных сил РФ. Угрозами назывались нарушение воздушного пространства стран Балтии, крупномасштабные учения и милитаризация вдоль границы НАТО (Латвию, Литву и Эстонию ..., 2018: Электронный ресурс). А как иначе должна вести себя Россия, когда Североатлантический Альянс 
придвинулся к ее границам и проводит в оскорбительной форме действительно крупномасштабные учения, всем своим видом и соответствующими заявлениями западных политиков показывая, что эти учения носят антироссийский характер? Как иначе реагировать, когда в странах восточной Европы установлены американские ПРО? К тому же Россия проводит учения далеко от границ со странами НАТО, чего не скажешь о последних. Что касается нарушений воздушного пространства, почему-то, когда самолеты НАТО вторгаются в российское пространство, западные политики не торопятся признавать вину и каяться. Нет никаких провокационных действий со стороны России, однако НАТО совершает недружественные акты против РФ. Не стоит путать провокации с ответом на провокации, и прежде чем обвинять Россию, следует ознакомиться с хронологией событий. Продемонстрированная «логика», которой болеют не только прибалтийские, но и в целом западные элиты, - обычная инсинуация, с помощью которой можно не просто оправдать любого агрессора, а его невинную жертву представить в качестве агрессора.

«Нет сомнения, что союзнической связи между США и государствами Балтии определено продолжаться. Нам приятно, что новая стратегия национальной безопасности США предвидит усиление восточного крыла НАТО», - заявили министры Эстонии, Латвии и Литвы (Страх и трепет .. 2018: Электронный ресурс). Это не смелость и отвага, а всего лишь пресловутый конформизм и заискивание перед наиболее могущественными силами. Конечно, когда они говорят о союзничестве, речь не идет о горизонтальных и равных отношениях. Сугубо вертикальное, иерархическое взаимодействие, где один субъект - полновластный хозяин, а другой - его послушный вассал, на дипломатическом языке называется союзничеством.

Мировой гегемон постоянно высказывает свою поддержку Прибалтике и настраивает ее против России. Так, в 2014 г. Джо Байден посетил Эстонию, Латвию и Литву и заверил глав этих государств в том, что приверженность Штатов статье 5 договора НАТО «серьезна» и «решительна». То же самое им говорил Б. Обама. Статья 5 обязывает США начать войну против России, если она нарушит территориальные границы любого из балтийских государств (см.: Бьюкенен, 2015). Только зачем ей это делать? Скорее всего, американские обещания по защите Прибалтики от «зловещей» России являются пустыми. Ведь истории того, как США бросали своих «союзников», богаты злачными подробностями, Вашингтон часто уходил от выполнения своих обязательств по заключенным договорам. Или же, если мировой гегемон снизошел бы до защиты Прибалтики от напавшей на нее России, это делалось бы путем НАТОвской бомбежки наполненных русскими войсками Латвии, Эстонии и Литвы и, соответственно, убийствами мирных жителей. Во- 
первых, США этим неоднократно отличились. Во-вторых, США бомбили целые страны и народы, не жалея никого, и сложно представить, что они будут защищать тех, кто к их цивилизации и культуре не имеют отношения. Им нужна не процветающая Прибалтика, а разбитая Россия. Только этих простых истин не признают прибалтийские политики и продолжают играть в игру «нас защищают США», которые по факту оккупировали этот регион и навязывают ему вектор политических, экономических и дипломатических действий.

Недаром прибалтийские «смельчаки» во всем вторят американским лоббистам, безоценочно и некритично перенимают и тиражируют пропаганду «вашингтонского обкома», разрешают (а что им остается делать?) строить на своей территории американские военные базы. Примечательный факт: Пентагон согласился оплачивать медицинские операции пожелавшим сменить свой пол военнослужащим; из всех республик бывшего СССР открытым трансгендерам разрешили служить в армии только в Эстонии (Эстония открыла ... , 2018: Электронный ресурс).

Когда прибалтийские «смельчаки» снова нагнетают волну русофобии, стоит говорить о «смелости» волчонка Табаки из «Книги джунглей» Р. Киплинга. Или имеет смысл вести речь о смелости знаменитой Моськи. А если бы эти моськи не находились под американским крылом (точнее, крышей), едва ли стали бы они использовать настолько агрессивную риторику по отношению к России. Сидели бы тихо, боялись высунуться и даже не помышляли о том, чтобы лаять на слона (точнее, медведя). Но когда есть «крыша», да еще она заставляет поднимать лай, - совсем другое дело. Если бы именно Россия вместо США начала задавать мировую повестку дня, восточноевропейские элиты вмиг переобулись бы и принялись искать доброго отношения к себе от РФ, которую бы они представили в качестве нового хозяина. Актуальным остается вопрос «Кому бы сдаться?» - особенно когда сдаваться есть кому.

Только распростертая над Прибалтикой «крыша» не слишком помогает решать социально-экономические проблемы. Так, за последние десять лет из Латвии, население которой составляет около двух млн жителей, уехало более 300 тыс. человек. Центральное статистическое управление утверждает, что ежедневно из Латвии на постоянное место жительства уезжает около 60 человек. Глава профсоюза работников здравоохранения и социального ухода Валдис Керис сообщал, что в 2017 г. Латвия занимала третье место по сокращению численности населения в ЕС. В сейме республики заявили, что количество молодежи с 1990 г. сократилось в Латвии почти в два раза (см.: Раймонд Паулс ... , 2018: Электронный ресурс). Аналогичные проблемы наблюдаются в Эстонии и Литве. В целом страны Прибалтики во время су- 
ществования СССР жили значительно лучше. Теперь им остается находиться под оккупационным влиянием США, и, в условиях упадка экономики и оттока населения, делать кислую мину и имитировать радость от того, что мировой гегемон их защищает от агрессивной России, которая ранее, в период существования СССР, поддерживала в странах Балтии достаточный уровень жизни.

Внешняя разведка Эстонии в марте 2019 г. опубликовала доклад «Эстония в среде международной безопасности». В нем указывается, что Россия стремится развязать войну с НАТО, начать наступление через Эстонию, а заодно вмешаться в европарламентские выборы. Как всегда, было предложено на основе высказанной «информации» изолировать Россию от всякой международной активности, для начала запретить участие в спортивных соревнованиях (Вассерман, 2019b: Электронный ресурс). Только русофобы на то и русофобы, что у них нет доказательств своим сообщениям и прогнозам. И, конечно, если предсказание не сбудется, эстонские «футурологи» даже не подумают признать ошибку и посыпать голову пеплом. Ведь как американским и западноевропейским, так украинским или прибалтийским русофобам принятие ответственности за свои слова совершенно не свойственно. Они постоянно лгут о России и ее планах, и когда ложь становится очевидной, они продуцируют новую ложь. Так цепочка лжесвидетельств уходит в бесконечность... И все эти доклады один за другим наверняка действительно читают в Европе, смотрят на них как на авторитетные аналитические работы.

Президенты Латвии, Литвы и Эстонии однажды единым фронтом, в лучших традициях коллективизма и солидарности приняли решение об отказе участвовать в коалиции по борьбе с ИГИЛ (Ковалев, 2015: Электронный ресурс). Аргумент использовался один: участие в коалиции России. Это напоминает детский каприз «Я с тобой не играю». Только, в отличие от игры в песочнице, ситуация более серьезная. Ведь такая принципиальность может обернуться «дурной принципиальностью», поскольку она способна в перспективе подорвать безопасность в том числе прибалтийских стран. Если с организованным терроризмом не бороться, он имеет шансы усиливаться и в дальнейшем совершать территориальную экспансию. Можно сказать, своими активными действиями в Сирии Россия защитила ряд стран от такой перспективы.

Представим себе военное укрепление и территориальное расширение ИГИЛ, которое не встречается ни с какими препятствиями. Оно способно перерасти в крайне мощную силу и стать общим врагом как для русских, так для европейцев и прибалтов. Отказ вступать в коалицию с Россией выглядит крайне глупо. А если Россия борется с реальным злом, которое было на международном уровне квалифицировано как зло? Или если Россия будет проти- 
востоять нападению инопланетян, угрожающих всему человечеству? Прибалтика останется при своих принципах и предпочтет погибнуть, но не «замазать» себя сотрудничеством с восточным соседом? Позиция «Лучше умру, но с тобой на одном поле никогда не сяду» внешне выглядит весьма героической. Однако рискну высказать гипотезу, что если Россия станет центром силы, былая идеологическая принципиальность даст трещину.

Ничего удивительного в таком шаге Прибалтики мы не видим. Не должны вызывать удивления никакие действия, которые укладываются в идеологическую парадигму «Куплю билет, но не поеду, если водителем является русский». Ведь только лишь на словах декларируется независимость балтийских стран. На деле же они подчинены воле США и вынуждены играть по их правилам. Они же явно не желают, чтобы террористы получили по заслугам, поэтому не стремятся допустить вклада своих вассалов в разгром ИГИЛ. Едва ли стоит ожидать аутентичной принципиальности от руководителей стран, которые во многом отдали свой суверенитет абсолютно беспринципным элитам мирового гегемона.

Россия боролась с террористами в Сирии, несмотря на крики в мировых СМИ, что она бомбит не тех, кого надо, уничтожает мирное население, помогает Б. Асаду осуществлять химические атаки против мирных жителей. Ни один из этих русофобских тезисов обоснован не был. Однако было доказано, что США активно помогали боевикам ИГИЛ, сотрудничали с ними, вывозили их (Ильин, 2019). Получается, главы прибалтийских государств солидаризировались не просто с мировым гегемоном, а с наиболее агрессивными исламскими фундаменталистами, которые отрезают людям голову просто за инакомыслие.

\section{ПЕРЕПИСАННАЯ ИСТОРИЯ}

Высшие чиновники Латвии, Литвы и Эстонии уже давно активно дискредитируют Россию, используя самую примитивную русофобскую риторику. Они обвиняют нас в вековой оккупации и в экспансионистских стремлениях в настоящем времени. Только за годы так называемой независимости Россия ни словом, ни делом не проявила желания захватить прибалтийские земли, не говоря уже о Европе в целом. Что касается вековой оккупации, вспомним историю.

Финляндия, Эстония и Латвия никогда не были суверенными государствами. Россия выкупила эти территории в XVIII в. у шведов. Именно выкупила, заплатив деньги побежденной Швеции. Как раз в составе России эстонцы и латыши обрели свою национальную принадлежность. А теперь прибалтийские элиты вещают о какой-то российской оккупации. Если уж эти русофобы, как и большинство других, вооружены либеральным сознанием, то 
пусть помнят либеральный же тезис о священном праве частной собственности. Так вот Прибалтика и была этой собственностью у России. Обратимся к истории более подробно.

Россия приобрела за деньги прибалтийские территории по Ништадтскому мирному договору в 1721 г. у побежденных в войне шведов. Сделкой никто не возмущался, правомерность вхождения прибалтийских земель в состав России никто не оспаривал. Напротив, законность выхода Эстонии и Латвии из России в 1918 г. весьма сомнительна. Англия и Франция выступали гарантами всех государственных образований, которые появились после 1917 г., будучи нарезанными из территорий Германской, Австро-Венгерской и Российской империй (см.: Стариков, 2014). Этого следует ожидать, ведь британский истеблишмент вместо международного права признает те новые гособразования, которые ранее были частями великих геополитических оппонентов Британии. Просто невозможно не признать разделение врага на части, которое одновременно с этим есть его ослабление. Напротив, присоединение оппонентом территорий, пусть оно хоть трижды соответствует международному праву и всевозможным принципам гуманизма, будет отрицаться как нелегитимное. Самый яркий тому пример - Крым.

Латгалия (одна из частей Латвии) вошла в состав Российской империи после раздела Польши в 1772 г., и эту сделку тоже никто не оспаривал. Курляндия (другая часть Латвии) была куплена Екатериной II у герцога Курляндского в 1795 г. Говорили на этих территориях люди в те времена на немецком языке, а в Вильнюсе вместо литовского господствовал польский язык. Никаких Латвии и Эстонии как политических единиц до их вхождения в Россию не существовало, вместо этих названий были Эстляндия и Лифляндия. Независимость этих государств была провозглашена только в начале XX в. Именно в составе России эстонцы и латыши обрели свою национальную принадлежность, почему-то не обретя ее в составе других стран. Развитие культуры и языка Эстонии и Латвии хронологически совпадает с их включенностью в российское государство. Причем на территории Эстляндии русские отменили крепостное право в 1816 г., в Курляндии - в 1817 г., в Лифляндии — в 1819 г., в Латгалии — в 1861 г. (см.: Стариков, 2018). Если национальное становление называть русской оккупацией, тогда прибалтийские русофобы правы.

Нападки на Российскую империю не ушли в прошлое, оставаясь сегодня неким политическим капиталом. Царскую Россию называют страной, которая эксплуатировала различные народы, в том числе балтийские. Однако поляки и финны в Российской империи получили конституцию, когда у русских ее не было. В Прибалтике крепостное право отменили раньше, чем в России. Немцы, кавказцы и другие народы находились при дворе (Фурсов, 
2007: Электронный ресурс). Если это называть империей, непонятно, как тогда следует именовать государства, которые грабили колонии и отдавали привилегии одному — титульному — народу.

Группа самоназначенных политиков провозгласила независимость части России в 1918 г., назвав ее Эстонской Республикой. Тогда — в условиях гражданской войны - русская армия ушла из Таллина, и группа сепаратистов этим воспользовались. Причем Великобритания, США и Франция быстро признали Эстонию и Латвию, которых никогда раньше не существовало (Стариков, 2017). Ведь конкурирующая с ними Россия благодаря отторжению территорий изрядно ослабилась - следовательно, нужно данное ослабление приветствовать. И потому западные пропагандисты о прибалтийском сепаратизме не вспоминают. Наоборот, они (и вторящие им прибалтийские русофобы) говорят, что СССР в 1940 г. оккупировал Прибалтику. Во-первых, она незаконным путем вышла из-под российской юрисдикции во время гражданской войны. Незаконность обосновывается тем, что ранее независимых Эстонии и Латвии не существовало. Во-вторых, в декабре 1939 г. Латвия подписала с СССР договор о взаимопомощи, согласно которому на территории Латвии создавались советские военные базы. Если это оккупация, данный термин следует использовать в отношении всех стран (в том числе прибалтийских), где сейчас размещены военные базы США. Тогда же, еще до вхождения Литвы в состав Советского Союза (!), Литва получила от СССР Виленскую область, которая (с 1795 по 1918 г.) принадлежала Российской империи, затем - Литве, потом (до 1939 г.) - Польше. Это ли не щедрый подарок? В 1940 г. СССР ввел с согласия местного правительства дополнительные войска в Латвию ради защиты от Гитлера. Вскоре правительство Латвии само попросило о принятии в состав СССР. Никто не оказывал Советскому Союзу сопротивления; последний не разоружал прибалтийские армии и никакой войны этим государствам не объявлял (см.: Стариков, 2018). Где здесь оккупация?

Прибалтийские элиты высказывают претензии России за то, что после установления у них советской власти в 1939-1940 гг. осуществлялась депортация в Сибирь на национальной основе. Однако в депортациях вместо национального использовался социальный признак; среди депортированных было много поляков и евреев, которые составляли местную буржуазию. Также и репрессии в Прибалтике были не сильнее тех, что происходили в России, и продолжались более короткое время (Кагарлицкий, 2012).

В марте 2019 г. заместитель председателя ультраправой консервативной народной партии Эстонии Хенн Пыллуаас заявил, что Россия должна вернуть Эстонии Ивангород и Печерский район Псковской области или заплатить за их нахождение в составе РФ. Как обычно, риторика крутилась во- 
круг тезиса, согласно которому Россия силой захватила территории у Эстонии. Пыллуааса не смущают простые исторические факты. В период гражданской войны эстонцы оторвали от России земли Петроградской и Псковской губерний. Ивангород - русская земля, упоминание в летописи которой датировано 1470 годом. Вместо Эстонии тогда было Новое Село - будущий Ивангород. В 1492 г. русские заложили в этом месте крепость, которая в честь московского князя Ивана III Васильевича была названа Ивангородом (см.: Вассерман, 2019b: Электронный ресурс; Королева, 2019: Электронный ресурс; Орлов, 2019: Электронный ресурс). Правильней было бы России требовать от Прибалтики деньги за те вложения, которая Россия внесла в этот регион начиная даже не с его советского развития, а со времен выкупа Петром у Швеции прибалтийских территорий.

Советский режим выстроил в Прибалтике, Польше и других странах огромное количество предприятий, а теперь местные пропагандисты обвиняют его в оккупации. Да и ранее история взаимоотношений между русскими и жителями прибалтийских территорий была не настолько трагичной, какой ее стали рисовать русофобствующие пропагандисты. Так, по замечанию А. Н. Тарасова, предкам нынешних эстонцев, литовцев и латышей помогали псковичи и новгородцы в борьбе против крестоносцев (Тарасов, б/д: Электронный ресурс; 2002). И что произошло бы с Прибалтикой, не «оккупируй» Россия ее в свое время? Получили бы те же Эстония и Латвия какой-нибудь суверенитет? Если лидеры соответствующих стран считают, что Россия должна им контрибуцию за оккупацию, а коллективный Запад вторит в унисон этому «мнению», то Россия по более справедливым основаниям может выставить счет Литве и Польше за оккупацию некоторых российских территорий. Также правомерно выставить аналогичный счет Франции за Наполеона, Германии - за Гитлера. Причем, вспоминая гитлеровское варварское нашествие, речь стоит вести о требованиях практически ко всей Европе, которую объединил бесноватый фюрер против России. Заодно неплохо бы выглядело аналогичное требование по отношению к США, которые грабили Россию на протяжении 1990-х гг. Но дело в том, что Россия не мыслит такими категориями, не выставляет никому счета за дела давно минувших дней. Это к вопросу о злопамятстве «кровавой» России.

Вся прибалтийская инфраструктура была выстроена именно во времена СССР. Аграрные и в целом экономически отсталые страны Балтии превратились в развитые с точки зрения индустрии и культуры республики в составе СССР. Они получили: национальные академии наук; техническую, гуманитарную и военную интеллигенцию; достойное образование; во властных структурах на республиканском и союзном уровне латыши, эстонцы и литовцы представлялись пропорционально (см.: Залиханов, Степанов, 2018). Но 
русофобские и десоветизирующие пропагандисты продолжают говорить, что их республики были оккупированы. Вот такими «благодарными» остались прибалты и украинцы по отношению к Советскому Союзу, который обеспечил им экономический рост. Их не смущает следующее: почему-то в «оккупационных режимах» действовали те же законы, что и во всем СССР, в «оккупированных» республиках шло полномасштабное строительство всего, что только можно построить. Где же это видано, чтобы колония развивалась примерно вровень с метрополией, чтобы в колонию вкладывалась масса средств для ее развития? Тот же колониальный гегемон Британия никогда такого не допускала.

Прибалтийские власти спустя более 25 лет после обретения независимости все не могут посчитать, сколько Россия им должна за советскую «оккупацию». Цифры у них разнятся и постоянно меняются. Даже Г. Киссинджер отмечает, что удержание Советским Союзом своих восточноевропейских сателлитов было связано не с приращением советских ресурсов, a c их утечкой (Киссинджер, 1997). Конечно, мы не можем Киссинджера воспринимать как своего идейного союзника, однако его заявление явно противоречит господствующей сегодня в странах Восточной Европы идеологеме, согласно которой СССР ради собственного процветания изымал ресурсы этих стран. Так стоит ли говорить о том, будто СССР выжимал все соки из своих сателлитов? Конечно, нет.

Вильнюс и Виленский край ранее перешли Советскому Союзу от распавшейся Польши. СССР сразу же подарил их Литве. За юго-западную часть Литвы (Вилковижский район) советское правительство заплатило в 1941 г. Германии \$7,5 млн. Город Клайпеда был отобран Германией у Литвы в 1939 г., которая получила его после окончания Первой мировой войны. Лондон и Париж никак не отреагировали на эту германскую аннексию, хотя Англия и Франция являлись гарантами статуса Клайпеды. Более того, Туманный Альбион, а за ним остальное «цивилизованное» человечество, моментально признал вхождение Клайпеды (Мемеля) в состав Рейха. Лишь в 1945 г. Сталин вернул этот город Литве (см.: Стариков, 2014, 2017).

Выйдя из состава СССР, Литва не вернула России полученный ранее подарок - ни Вильнюс, ни Клайпеду. Вместо этого литовцы в унисон почти со всем Западом заговорили об их оккупации Советским Союзом. Думается, сначала нужно вернуть полученные от Союза территории, а потом уже обвинять в оккупационных действиях. Так обвинения по крайней мере будут выглядеть последовательно и хотя бы немного правдоподобно. Но такая последовательность, похоже, недоступна и не характерна для наших прибалтийских коллег. Вместо этого они активно считают «ущерб», который причинил им СССР, и выставляют нынешней России различные счета. Заодно Литве не 
мешало бы для все той же политической последовательности предъявить претензии Великобритании и «прогрессивному» человечеству за признание перехода Клайпеды в состав Германии. Но об этом литовцы молчат.

Во время «оккупации» прибалтийских стран не последовало никаких восстаний и массовых актов недовольства, а советская армия, в свою очередь, не расформировывала армии этих стран, как надлежит поступать оккупантам, желающим предупредить возможное сопротивление. Когда происходила «оккупация» Литвы, Латвии и Эстонии в 1940 г., почему-то никто ей не сопротивлялся (см.: Стариков, 2016). Так, может, потому и не сопротивлялись, так как хотели стать частью СССР. И почему-то в «оккупированной» зоне рос уровень жизни, строились предприятия, дороги, дома, развивалась промышленность, осуществлялись масштабные вложения в развитие образования, науки, здравоохранения - конечно, в соответствии с решениями Кремля.

Союзники не высказывали никаких протестов в связи с нахождением прибалтийских республик в составе СССР. Более того, как пишет Г. Меттан, они подтвердили присоединение Прибалтики к СССР на Ялтинской конференции в 1945 г.; швейцарский журналист также упрекает прибалтов за их русофобию напоминанием о том, что до 1945 г. на их территории правили профашистские режимы, преследовавшие евреев (Меттан, 2016). Может, целесообразно, чтобы Россия как правопреемница Советского Союза выставила счет прибалтийским странам за те деньги, которые были вложены в их развитие? Но историческая истина прибалтийских лоббистов не интересует, и потому они решаются обвинять Россию в оккупации, в стремлении снова ввести войска и вообще в различных несусветных грехах.

В 2005 г. лидеры Литвы и Эстонии отказались приехать в Москву на празднование годовщины победы над нацизмом. Этим они показали свое неприятие верной исторической точки зрения. Совершивший тогда поездку по Восточной Европе Дж. Буш осудил советскую оккупацию балтийских республик (см.: Цыганков, 2015), не предоставив никакой весомой аргументации для этого осуждения.

Дж. Кьеза рассказывает интересную историю. В 2006 г. официально вышло правительственное издание под названием «Три оккупации Латвии». Этот пропагандистский памфлет распространялся в Брюсселе среди европейских делегаций. В нем речь идет о советской «оккупации» 1939 г., о немецкой оккупации 1941 г. и снова о советской, датированной периодом с 1944 по 1991 гг. Первой посвящается около десяти страниц, второй - всего четыре, а третьей отведена остальная часть книги в сто страниц. В документе нет ничего о немецкой оккупации Ливонским орденом и тевтонскими рыцарями, нет сведений о шведской оккупации XVII-XVIII вв. Забыли авторы рассказать и 
о пребывании Латвии в составе Российской империи. Однако советскую власть они обильно критикуют, в том числе за то, что она положила конец немецкой оккупации. Советы вызывают больше идиосинкразий, чем нацисты (Кьеза, 2016). Речь идет не о фальшивке, созданной какими-то маргиналами, а об официальном документе, вышедшем с одобрения правительства. Подобные документы говорят о глубине деградации элит, степени наглости в фальсификации истории, симпатии к нацизму и, конечно, зоологической русофобии.

Когда некоторые русофобствующие представители Прибалтики говорят, что Гитлер стремился их освободить от коммунизма, они явно кривят душой. Рейх вовсе не планировал оставлять в целости и сохранности такие нации, как эстонцы, латыши и литовцы. В его планах было сделать из них свинопасов и горничных, обеспечивающих нужды Германии. В Литве, Латвии и Эстонии чуть ли не боготворят Гитлера, а Сталина считают вероломным захватчиком. Конечно, если бы фюрер одержал победу, он «освободил» бы прибалтийские страны от СССР, но вряд ли он освободил бы их от репрессий и откровенного геноцида.

Эстонский историк и эксперт по внешним отношениям Тунне Келам заявил, что Евросоюзу необходима единая интерпретация истории Европы, чтобы не было противоречий в объяснениях, которые могут усугубиться под влиянием заинтересованных левых сил (Латвийская газета ... , 2010: Электронный ресурс). Это очень интересное заявление. Получается, противоречия в исторических объяснениях усугубляются под влиянием именно левых сил, а правые силы, значит, в этом усугублении априори не участвуют. Далее Келам сказал: «Окончание войны принесло свободу европейским государствам, но многие коллеги в европарламенте не знают, что мы-то не были освобождены. Пока простые русские, так же как немцы, не признают свою вину в преступлениях своего государства, до тех пор коммунизм не будет полностью побежден. Мы должны помочь России в преодолении этих призраков прошлого. У нас есть право бороться за понимание нашей истории и мы обязаны познакомить с этой историей Европу» (цит. по: там же). Фраза об обязанности познакомить Европу с историей означает ознакомление Европы с псевдоисторией. Индустриализация Советским Союзом Прибалтики воспринимается как преступление. Хотя нет, манипуляторы типа Келама специально не вспоминают эту страницу истории, ведь она портит все их идеологическое построение. Что касается их долженствованию помочь России, очевидно, о какой «помощи» идет речь. Содействие транснациональным силам колонизировать Россию по всем фронтам сопрягается с помощью России; оксюморон по-оруэлловски. Так, может, Гитлер тоже хотел помочь в свое время нашей стране? Отъем у народов Балтии и Украины их подлинной исто- 
рии, касающейся жизни в Советском Союзе, следует квалифицировать как нарушение исторической объективности, а заодно демократии и прав человека.

В 2007 г. накануне Дня Победы эстонские власти вздумали перенести Бронзового солдата, поставленного в память о погибших советских войнах. Премьер-министр Эстонии Андрус Ансип сказал о похороненных в братской могиле под монументом русских пьяницах и мародерах (Резчиков, 2007: Электронный ресурс). Власти страны постулировали отсутствие разницы между отрицанием холокоста и отрицанием преступлений советского коммунизма. Перенос мемориала был мотивирован тем, что освободило Таллин от фашистов якобы легитимное эстонское правительство, а вовсе не красноармейцы. Этим эстонские политики предали память тысяч советских солдат, которые погибли во время освобождения Эстонии (Меттан, 2016).

Решение о переносе памятника в Таллине противоречило воле общественности и вызвало уличные протесты, в которых погиб один протестующий и были арестованы 1200 человек. Разгоняя демонстрацию, эстонская полиция проявила особую жестокость. В ответ русские активисты осуществили осаду посольства Эстонии в Москве, о чем должностные лица НАТО и Евросоюза высказали недовольство. Россия обратилась в ЕС с просьбой отговорить Таллин от провокаций, но европейские лидеры высказали солидарность с Эстонией с представлением о русском освободителе как агрессоре. США тоже заняли позицию Эстонии (К. Райс осудила осаду эстонского посольства в Москве), пригласив президента Эстонии Т. Ильвеса на встречу с Дж. Бушем. Ильвес постулировал отсутствие разницы между нацистами и коммунистами, назвал советские войска шайкой бандитов, а советский период Эстонии - эрой апартеида. США заодно осудили протесты в Таллине, а перенос Бронзового солдата назвали внутренним делом Эстонии. Американское русофобское лобби заявило, что СССР не отличался от нацистской Германии или даже был хуже ее; он вместо освобождения Прибалтики оккупировал ее и лишил исторической принадлежности к свободному миру (Цыганков, 2015). В таком случае стоит критиковать самих же США и Британию, бывших союзниками СССР в борьбе с вермахтом. Они спокойно отнеслись к включению Прибалтики в СССР по договору Молотова-Риббентропа. Они внесли вклад в создание послевоенного мирового порядка. И если СССР не освобождал Прибалтику, неясно, каким образом он потерял своих военных в боях за страны Балтии.

Борьба польских, прибалтийских и украинских русофобов против памятников советской эпохи — это не подлинное отрицание прошлого, а всего лишь акт бессильной истерии в борьбе с прошлым, доказывающий, что можно снести артефакт, но невозможно уничтожить память о самой эпохе. Это 
акт, от которого ожидается, что он приведет не просто к исчезновению прошлого, но и к исчезновению его исчезновения; ликвидация прошлого должна ликвидироваться, не оставив никаких следов, подмена в картине содержания должна остаться незамеченной. Однако фальсификации видны невооруженным взглядом, и потому «затереть» само стремление к деконструкции истории не получается - это касается не только борьбы с памятниками, а переворачивания истории в самом широком смысле. Прошлое нельзя победить, сколько ни сноси памятники и не заменяй их на новые - отражающие «современный политический взгляд». Подлинной борьбы с прошлым быть не может, так как само прошлое было подлинным.

В литовском Музее жертв геноцида понятие «геноцид» применяется исключительно к деяниям русских с народами Балтии, про нацистов и их пособников речи нет. Также игнорируется роль народов Балтии в холокосте. Некоторые должностные лица Прибалтики высказывают поддержку ветеранам СС как борцам за свободу и поощряют возрождение прогитлеровских настроений. Так, эстонский премьер-министр Андрус Ансип почтил память участников обороны, воевавших на стороне рейха. 8 мая 2007 г. он возложил венок к мемориалу эстонским фашистам. Защищающие страны Балтии Штаты совершенно не озабочены этим фактом, как и дискриминацией русских в Прибалтике, a Freedom House оценивает Эстонию и Латвию как свободные демократические страны, хотя даже Amnesty International заявило, что 10 \% жителей Эстонии - лица без гражданства, русскоязычное меньшинство не имеет экономических, социальных и культурных прав. Когда председатель Парламентской ассамблеи Совета Европы (ПАСЕ) призвал правительства Прибалтики сконцентрировать внимание на положении русскоязычного меньшинства, Eurasia Daily Monitor осудила его в принятии антиэстонской пропаганды России и неспособности потребовать от РФ осуждения своей тоталитарной истории (Цыганков, 2015). Т. е., если Россия не желает осуждать несуществующую оккупацию, русскоязычных людей позволительно дискриминировать. Причем позволяет это делать официальный Запад, на словах осуждающий нацизм и какие-либо формы сегрегации. Добавим, что в ПАСЕ Россия была лишена права голоса, но европейцы при этом требуют в 2019 г. от РФ возместить невыплаченные взносы в ПАСЕ. Т. е. Россия не имеет в этой во многом русофобской организации никаких прав, но деньги за членство платить должна.

Организация «Даугавские ястребы», которая проводит в Риге марш эсэсовцев, была создана в Великобритании сразу после Второй мировой войны. В 1947 г. в Англии был основан фонд, который до сих пор помогает ветеранам СС, а в 1991 г. его отделения появляются в Латвии (см.: Стариков, 2011). Это еще одно доказательство двойных стандартов англосаксонской 
любви к демократии и того, что англосаксам свойственно подпитывать в странах СНГ ненависть к России. Прибалтика им нужна не просто как очередной регион влияния и наживы, а заодно как средство давления на Россию, как инструмент недопущения России к статусу морской державы.

Банк России выпустил в обращение монеты номиналом в 5 рублей, посвященные городам-столицам государств, которые были освобождены Советскими войсками от немецко-фашистских захватчиков: Бухарест, Киев, Минск, Вильнюс, Белград, Берлин, Будапешт, Прага, Рига, Таллинн, Вена, Бритислава, Варшава, Кишинев. Политический директор МИД Литвы высказал недовольство по поводу выпуска в России монеты, посвященной Вильнюсу, т. е. чиновник недоволен освобождением советскими войсками Вильнюса от немецких фашистов. Но он по крайней мере заявил, что нацистскую оккупацию сменила советская, т. е. признал нацистов оккупантами. Однако в называющих себя демократическими странах Прибалтики часть номенклатуры открыто признаются в симпатиях к фашистам. Они по-прежнему думают, что в случае победы немцев в войне местные народы зажили бы счастливо. Только, как уже говорилось, такая точка зрения напрочь противоречит гитлеровским планам.

\section{ЗАКЛЮЧЕНИЕ}

Немаловажная русофобская идея - связывание жестокого и кровавого коммунизма с русскими, приписывание преступлений коммунизма именно русским. Во многих странах, особенно в Польше, на Украине и в прибалтийских государствах, политики принялись во всем обвинять Россию, забывая, что они сами работали на советскую систему, проповедовали коммунистические убеждения. Получилось, преступниками являются русские, а другие народы выступают жертвами. Во-первых, коммунизм как идеология был изобретен совсем не русскими. Мор, Кампанелла, Сен-Симон, Фурье, Маркс, Энгельс были европейцами. Во-вторых, более объективно коммунизм было бы характеризовать не через «преступления», а через значимые и прорывные достижения. И тогда коммунизм уже рассматривается вовсе не в качестве метафизического зла, в котором можно кого-либо обвинять. В-третьих, Сталин — это воплощение зла для русофобов - был грузином. И в его окружении находилось много представителей различных национальностей: Дзержинский - поляк, Свердлов, Каменев и Зиновьев - евреи, Орджоникидзе грузин, Фрунзе - молдаванин. В-четвертых, в разных уголках мира, на разных континентах существуют государства, позиционирующие себя как коммунистические. Коммунизм, как и ряд других идеологий, носит интернациональный характер. Китайский, кубинский, вьетнамский коммунизм - вовсе не проявления русскости. В Европе левые партии в свое время имели серьез- 
ный вес, а коммунистические идеи овладевали мировоззрением довольно широких масс людей. И основывались они не на русских коммунистических взглядах, а на европейском наследии. Наконец, винить исключительно русских в коммунизме - значит солидаризироваться с Гитлером, который тоже подходил к этому вопросу с национальной стороны и считал коммунизм изобретением евреев. Короче, обвинителям следует сказать: добро пожаловать в клуб фашистов.

Если обвиняете в коммунизме русских, будьте последовательны. Давайте обвинять во всех ужасах либерализма американцев. Американцы везде (бомбежками, экономическими удавками или цветными революциями) устанавливают либерализм, тянут всех и каждого в систему свободной торговли. После этого страны и народы обваливаются в нищету, а национальные экономики становится действительно открытыми - перед транснациональными корпорациями и международными спекулянтами. Они открываются для своего уничтожения, что и происходит в странах с насажденным либерализмом.

Воспоминание Победы в частности и войны в целом должно быть однозначным, иметь строго определенную трактовку. Оно является значимым идентификационным фактором. Для ряда народов таким фактором выступает воспоминание о холокосте, которое тоже подвергается расшатыванию. Так, в Эстонии открылась посвященная холокосту выставка, в пресс-релизе которой сказано, что спонсором является министерство культуры Эстонии. Организаторы заявили о своем стремлении «с юмором взглянуть на холокост». Надпись «Холокост» размещена на фоне голливудских холмов. В видеоинсталляции газовой камеры Освенцима голые люди смеются и играют в салочки. На одном полотне счастливые узники Освенцима представлены улыбающимися из-за колючей проволоки. Ранее, в 2012 г., местная энергосбытовая фирма опубликовала на сайте в качестве рекламы фото ворот в Освенцим и надпись «Газовое отопление - гибкое, удобное и эффективное». Позже одна из эстонских газет разместила рекламу таблеток для похудения доктора Менгеле (имя нацистского врача, который известен садистскими экспериментами над узниками). На фотографии изображены истощенные люди из Бухенвальда и написано: «В лагере не было ни одного толстого» (см.: Ольховская, 2015: Электронный ресурс). Очевидно, что когда воспоминаниям о таких трагических событиях придается сарказм, они развенчиваются, теряется их однозначность. Они теряют свой трагизм благодаря такой кощунственной акции. Юморизация может быть только одним из шагов в процессе десакрализации таких воспоминаний. Сначала вместо трагической представляется юмористическая репрезентация, которая стирает ужасы холокоста. Затем юморизация может стать главной темой не одной выставки, а всего медийного тренда, посвященного данной теме. После этого «выяснится», что в конц- 
лагерях никого не убивали и не мучили (уже давно такая риторика существует). Далее заявят о том, что никакого холокоста не было. А потом Гитлера представят как великого гуманиста и как бедную ни в чем не виновную сталинскую жертву. Если такую выставку организует и спонсирует не просто толпа сумасшедших, кучка циников, а министерство культуры страны, это дает повод задуматься. Одно дело, когда несколько маргиналов реализуют циничный до эпатажа проект. Совсем другое дело, когда он поддерживается или даже организуется правительством.

Наконец, если кто-нибудь с таким же юмором устроит инсталляцию, посвященную расправам над прибалтийскими фашистами, соответствующие организации прибалтийских стран (и наверняка их правительства), мягко говоря, проявят возмущение. Или же в случает юморизации событий 11 сентября американцы поднимут вой, поскольку для них эта дата - святое. Но почему-то над святым для одних можно смеяться, а над святым для других нельзя. В современном мире проявляется тренд на запрет высмеивать не святости, а псевдосвятости. Европейскую гей-толерантность высмеивать нельзя. А все, что этим «ценностям» противоречит, видимо, можно и даже нужно.

Как в Прибалтике, так и во всем западном мире, стало правилом хорошего тона порицать пакт Молотова - Риббентропа, считая его советским актом пособничества Гитлеру. Как подобает в «цивилизованном» мире, пропагандисты не торопятся вспоминать мюнхенский сговор, на котором британцы просто отдали Гитлеру часть Чехословакии. В 1939 г. государства Прибалтики, где у власти были профашистские режимы, характеризующиеся политическими репрессиями и однопартийной системой, подписали с Германией договоры о ненападении. Но почему-то, судя по русофобским возгласам, получается, что только СССР подписал договор с нацистской Германией.

Против СССР вела войну не только упавшая в архаичный и истеричный нацизм Германия. Сторону вермахта приняло немалое количество европейских стран. Следует вспомнить, «что континентальная Европа пахала на Третий рейх в его войне с СССР; что итальянцы, венгры, румыны, прибалты и поляки воевали на стороне Гитлера; что каждый третий танк для восточного фронта был собран на чехословацких заводах; что с англичанами и французами, как отмечали многие, включая К. Шмитта, немцы воевали совсем иначе, чем с русскими; что в последние дни войны, в момент Endkampf'a рейхстаг защищали эстонские и французские эсэсовцы; что англосаксы и Ватикан организовали спасение десятков тысяч нацистов, многие из которых с конца 1940-х годов стали работать в США против СССР; что сегодня Запад благосклонно смотрит на марширующих по улицам Риги и Таллинна эсэсовцев и в то же время негодует по поводу символики страны, победившей этих эсэсовцев» (Фурсов, 2013: 23). 
Американские и европейские элиты расписались в поддержке нацизма в Прибалтике и на Украине, тем самым (и далеко не только этим) растоптав права человека и принципы демократии. Для США важно разогревать русофобские настроения в Восточной Европе, чтобы всячески ослаблять Россию, противодействовать ей в прокладке трубопроводов, экономически отделять ее от Европы. Геополитические амбиции США стоят во главе всего, и если они противоречат моральным нормам, демократическим принципам и международному праву, все это можно выбросить за борт как ненужный хлам. России тоже было бы полезно поссорить западные страны и играть на противоречиях. Но не такой ценой. РФ не идет на переписывание истории, обеление нацизма или каких-либо форм ксенофобии ради своих геополитических интересов.

\section{СПИСОК ЛИТЕРАТУРЫ}

Амин, С. (2007) Вирус либерализма: перманентная война и американизация мира / пер. с англ. Ш. Нагиба, С. Кастальского. М. : Европа. 168 с.

Бьюкенен, П. (2015) Секреты глобального путинизма : пер. с англ. М. : Алгоритм. 224 с.

Вассерман, А. А. (2019а) Нацизм остается евростандартом [Электронный ресурс] // Информационное агентство Kitaylife.ru. 9 мая. URL: https:// kitaylife.ru/politika/5267-nacizm-ostayotsya-evrostandartom-anatolij-vasserman.ht m [архивировано в WaybackMachine] (дата обращения: 14.08.2019).

Вассерман, А. А. (2019b) Открытым текстом 15.03.2019 [Электронный pecypc] // YouTube. 16 марта. URL: https://www.youtube.com/watch?v=uN-DZ GQMHFw [архивировано в WaybackMachine] (дата обращения: 21.03.2019).

Дело бывшего советского партизана Василия Кононова. Справка (2011) [Электронный ресурс] // РИА Новости. 1 апреля. URL: https://ria.ru/20110401/ 360024444.html [архивировано в WaybackMachine] (дата обращения: 16.08. 2019).

Делягин, М. Г. (2015) Россия перед лицом истории: конец эпохи национального предательства? М. : Книжный мир. 384 с.

Делягин, М. Г. (2016) Новая Россия. Какое будущее нам предстоит построить. СПб. : Питер. 320 с.

Залиханов, М. Ч., Степанов, С. А. (2018) Современный мир глобальных процессов в исследованиях Д. Марковича (к 85-летию со дня рождения выдающегося сербского ученого) // Век глобализации. № 4 (28). С. 51-61.

Ильин, А. Н. (2019) Война в Сирии. Хронология, американский интервенционизм, русофобия // Свободная мысль. № 3 (1675). С. 163-176. 
Кагарлицкий, Б. Ю. (2012) Марксизм: введение в социальную и политическую теорию. Изд. 2-е, испр. и доп. М. : Книжный дом «ЛИБРОКОМ». $320 \mathrm{c}$.

Киссинджер, Г. (1997) Дипломатия / пер. с англ. В. В. Львова ; послесл. Г. А. Арбатова. М. : Ладомир. 848 с.

Ковалев, В. (2015) Прибалтика отказалась сражаться с ИГИЛ в союзе с Россией [Электронный ресурс] // Ридус. 21 ноября. URL: https://www.ridus.ru/ news/205148 [архивировано в WaybackMachine] (дата обращения: 08.07.2019).

Королева, Е. (2019) Город раздора: Эстония может предъявить РФ претензии [Электронный ресурс] // Газета.ru. 11 марта. URL: https://gazeta.ru/ politics/2019/03/11_a_12236995.shtml [архивировано в WaybackMachine] (дата обращения: 07.08.2019).

Кьеза, Дж. (2016) Русофобия 2.0: болезнь или оружие Запада? М. : Эксмо. 288 с.

Латвийская газета: Итоги Второй мировой войны следует пересмотреть (2010) [Электронный ресурс] // Информационное агентство Regnum. 12 мая. URL: https://regnum.ru/news/1282814.html [архивировано в WaybackMachine] (дата обращения: 22.07.2019).

Латвию, Литву и Эстонию призвали «противостоять угрозам» со стороны России (2018) [Электронный ресурс] // Вести.Ru. 18 ноября. URL: https://www.vesti.ru/doc.html?id=3084511 [архивировано в WaybackMachine] (дата обращения: 03.08.2019).

Меттан, Г. (2016) Запад - Россия: тысячелетняя война. История русофобии от Карла Великого до украинского кризиса / пер. с фр. М. Аннинской, С. Булгаковой. М. : Паулсен. 464 с.

Москва ответила на «антироссийские» советы Эстонии Западу (2018) [Электронный ресурс] // Sputnik. 30 апреля. URL: https://ee.sputniknews. ru/politics/20180430/10434029/russia-otvetila-antirossijskije-sovety-estonia-west. html [архивировано в WaybackMachine] (дата обращения: 11.08.2019).

Мурниеце, И. (2010) Историческое решение по делу Кононова [Электронный ресурс] // ИноСМИ.Ру. 18 мая. URL: https://inosmi.ru/baltic/201005 18/159994780.html [архивировано в WaybackMachine] (дата обращения: 02.06. 2019).

Ольховская, Ю. (2015) В Эстонии набирает обороты скандал вокруг выставки, посвященной Холокосту [Электронный ресурс] // Первый канал. 10 февраля. URL: https://www.1tv.ru/news/2015/02/10/26885-v_estonii_nabiraet_o boroty_skandal_vokrug_vystavki_posvyaschennoy_holokostu [архивировано в WaybackMachine] (дата обращения: 02.07.2019).

Орлов, С. (2019) Эстония: Ивангород был нашим всегда, и мы его вернем [Электронный ресурс] // Свободная пресса. 12 марта. URL: https://sv 
pressa.ru/politic/article/227155 [архивировано в WaybackMachine] (дата обращения: 09.08.2019).

Раймонд Паулс сообщил об эмиграции своей семьи из Латвии (2018) [Электронный ресурс] // РИА Новости. 16 ноября. URL: https://ria.ru/culture/ 20181116/1532948285.html [архивировано в WaybackMachine] (дата обращения: 07.08.2019).

Резчиков, А. (2007) Героев назвали мародерами [Электронный ресурс] // Взгляд. 25 апреля. URL: https://vz.ru/politics/2007/4/25/79260.html [архивировано в WaybackMachine] (дата обращения: 04.08.2019).

Соколова, В. (2000) Дело Кононова слушают вновь [Электронный ресурс] // Независимое военное обозрение. 14 апреля. URL: http://nvo.ng.ru/ world/2000-04-14/1_kononov.html [архивировано в WaybackMachine] (дата обращения: 18.06.2019).

Стариков, Н. В. (2011) Хаос и революции - оружие доллара. СПб. : Питер. 330 с.

Стариков, Н. В. (2014) Геополитика: как это делается. СПб. : Питер. $368 \mathrm{c}$.

Стариков, Н. В. (2016) Власть. СПб. : Питер. 320 с.

Стариков, Н. В. (2017) Война: чужими руками. М. : Яуза ; Эксмо. 352 с.

Стариков, Н. В. (2018) Ненависть. Хроники русофобии. СПб. : Питер. $352 \mathrm{c}$.

Страх и трепет: Миксер попросил США усилить «сдерживание» России (2018) [Электронный ресурс] // Sputnik. 7 марта. URL: https://ru.sputnik-news. ee/estonian_news/20180307/9628620/Mikser-poprosil-usa-usilitj-sderzhivanije-rus sia.html [архивировано в WaybackMachine] (дата обращения: 28.07.2019).

Тарасов, А. Н. (2002) Откровения бывшего интеллигента // Свободная мысль - ХХІ. № 2. С. 64-69.

Тарасов, А. Н. (2003) О молодежи - в жанре доноса // Свободная мысль - XXI. № 3. C. 65-85. URL: http://scepsis.net/library/id_118.html [apхивировано в WaybackMachine] (дата обращения: 03.09.2018).

Тарасов, А. Н. (б/д) Фашизм в идеологии, ежовщина на практике [Электронный ресурс] // К новой идеологии - к новой революции! URL: http://saint-juste.narod.ru/aksionov.htm [архивировано в WaybackMachine] (дата обращения: 05.09.2018).

Фурсов, А. И. (2007) Русский ковчег [Электронный ресурс] // Завтра. 30 января. URL: http://zavtra.ru/blogs/2007-01-3151 [архивировано в WaybackMachine] (дата обращения: 02.05.2019).

Фурсов, А. И. (2013) «Нормальная наука» versus «аналитика» // Свободная мысль. № 2 (1638). С. 8-24. 
Цыганков, А. П. (2015) Русофобия: антироссийское лобби в США. М. : Эксмо. 448 с.

Эстония открыла двери казарм для трансгендеров из США (2018) [Электронный ресурс] // Sputnik. 6 марта. URL: https://ru.sputnik-news.ee/world _news/20180306/9607055/Boevyje-transgendery-usa-armija-estonia.html [архивировано в WaybackMachine] (дата обращения: 03.07.2019).

Дата поступления: 02.09.2019 г.

\section{REFERENCES}

Amin, S. (2007) Virus liberalizma: permanentnaia voina i amerikanizatsiia mira [The liberal virus: Permanent war and the Americanization of the world] / transl. from English by Sh. Nagib, S. Kastalsky. Moscow : Evropa Publ. 168 p. (In Russ.).

Buchanan, P. (2015) Sekrety global'nogo putinizma [Secrets of global Putinism] / transl. from English. Moscow : Algoritm Publ. 224 p. (In Russ.).

Wasserman, A. A. (2019a) Natsizm ostaetsia evrostandartom [Nazism remains a European standard]. Informatsionnoe agentstvo Kitaylife.ru, May 9. [online] Available at: https://kitaylife.ru/politika/5267-nacizm-ostayotsya-evrostan dartom-anatolij-vasserman.htm [archived in WaybackMachine] (accessed 14.08. 2019). (In Russ.).

Wasserman, A. A. (2019b) Otkrytym tekstom 15.03.2019 [Explicitly, 15.03.2019]. YouTube, March 16. [online] Available at: https://www.youtube.com/ watch?v=uN-DZGQMHFw [archived in WaybackMachine] (accessed 21.03. 2019). (In Russ.).

Delo byvshego sovetskogo partizana Vasiliia Kononova. Spravka [The case of the former Soviet partisan Vasily Kononov. Background]. (2011) RIA Novosti, April 1. [online] Available at: https://ria.ru/20110401/360024444.html [archived in WaybackMachine] (accessed 16.08.2019). (In Russ.).

Delyagin, M. G. (2015) Rossiia pered litsom istorii: konets epokhi natsional'nogo predatel'stva? [Russia in the face of history: The end of the age of national betrayal?] Moscow : Knizhnyi mir Publ. 384 p. (In Russ.).

Delyagin, M. G. (2016) Novaia Rossiia. Kakoe budushchee nam predstoit postroit' [New Russia. What kind of future we will have to build]. St. Petersburg : Piter Publ. 320 p. (In Russ.).

Zalikhanov, M. Ch. and Stepanov, S. A. (2018) Sovremennyi mir global'nykh protsessov v issledovaniiakh D. Markovicha (k 85-letiiu so dnia rozhdeniia vydaiushchegosia serbskogo uchenogo) [Contemporary world of global processes in D. Marković's research (To the 85th anniversary of the birthday of the prominent Serbian scientist)]. Vek globalizatsii, no. 4 (28), pp. 51-61. (In Russ.). 
Ilyin, A. N. (2019) Voina v Sirii. Khronologiia, amerikanskii interventsionizm, rusofobiia [The war in Syria: Chronology, American interventionism, Russophobia]. Svobodnaia mysl', no. 3 (1675), pp. S. 163-176. (In Russ.).

Kagarlitskii, B. Yu. (2012) Marksizm: vvedenie v sotsial'nuiu i politicheskuiu teoriiu [Marxism: Introduction to social and political theory]. 2nd edn., revised and enlarged. Moscow : LIBROKOM Book House. 320 p. (In Russ.).

Kissinger, H. (1997) Diplomatiia [Diplomacy] / transl. from English by V. V. Lvov ; afterword by G. A. Arbatov. Moscow : Ladomir Publ. 848 p. (In Russ.).

Kovalev, V. (2015) Pribaltika otkazalas' srazhat'sia s IGIL v soiuze s Rossiei [The Baltic states refused to fight against ISIL in alliance with Russia]. Ridus, November 21. [online] Available at: https://www.ridus.ru/news/205148 [archived in WaybackMachine] (accessed 08.07.2019). (In Russ.).

Koroleva, E. (2019) Gorod razdora: Estoniia mozhet pred"iavit' RF pretenzii [The town of contention: Estonia may make claims to the Russian Federation]. Gazeta.ru, March 11. [online] Available at: https://gazeta.ru/politics/2019/03/11 _a_12236995.shtml [archived in WaybackMachine] (accessed 07.08.2019). (In Russ.).

Chiesa, G. (2016) Rusofobiia 2.0: bolezn' ili oruzhie Zapada? [Russophobia 2.0: Disease or weapon of the West?]. Moscow : Eksmo Publ. 288 p. (In Russ.).

Latviiskaia gazeta: Itogi Vtoroi mirovoi voiny sleduet peresmotret' [Latvian newspaper: Results of the Second World War should be reconsidered]. (2010) Informatsionnoe agentstvo Regnum, May 12. [online] Available at: https:// regnum.ru/news/1282814.html [archived in WaybackMachine] (accessed 22.07. 2019). (In Russ.).

Latviiu, Litvu i Estoniiu prizvali «protivostoiat' ugrozam» so storony Rossii [Latvia, Lithuania and Estonia called to "stand up to the threats" of Russia]. (2018) Vesti.Ru, November 18. [online] Available at: https:/www.vesti.ru/doc.html

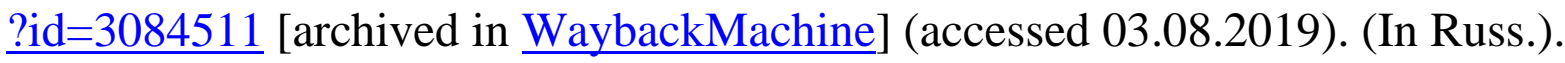

Mettan, G. (2016) Zapad - Rossiia: tysiacheletniaia voina. Istoriia rusofobii ot Karla Velikogo do ukrainskogo krizisa [The West vs Russia - a thousand year long war: Russophobia from Charlemange to the Ukrainian crisis / Russie-Occident, une guerre de mille ans: La russophobie de Charlemagne à la crise ukrainienne] / transl. from French by M. Anninskaia and S. Bulgakova. Moscow : Paulsen Publ. 464 p. (In Russ.).

Moskva otvetila na «antirossiiskie» sovety Estonii Zapadu [Moscow responded to Estonia’s “anti-Russian” advice to the West]. (2018) Sputnik, April 30. [online] Available at: https://ee.sputniknews.ru/politics/20180430/10434029/russia -otvetila-antirossijskije-sovety-estonia-west.html [archived in WaybackMachine] (accessed 11.08.2019). (In Russ.). 
Murniece, I. (2010) Istoricheskoe reshenie po delu Kononova [Historical decision on the case of Kononov]. InoSMI.Ru, May 18. Available at: https:// inosmi.ru/baltic/20100518/159994780.html [archived in WaybackMachine] (accessed 02.06.2019). (In Russ.).

Olkhovskaia, Yu. (2015) V Estonii nabiraet oboroty skandal vokrug vystavki, posviashchennoi Kholokostu [Scandal over the exhibition dedicated to the Holocaust is gaining momentum in Estonia]. Pervyi kanal, February 10. [online] Available at: https://1tv.ru/news/2015/02/10/26885-v_estonii_nabiraet_oboroty_ skandal_vokrug_vystavki_posvyaschennoy_holokostu [archived in WaybackMachine] (accessed 02.07.2019). (In Russ.).

Orlov, S. (2019) Estoniia: Ivangorod byl nashim vsegda, i my ego vernem [Estonia: Ivangorod has always been ours, and we will recapture it]. Svobodnaia pressa, March 12. [online] Available at: https://svpressa.ru/politic/article/227155 [archived in WaybackMachine] (accessed 09.08.2019). (In Russ.).

Raimond Pauls soobshchil ob emigratsii svoei sem'i iz Latvii [Raimonds Pauls reported on the emigration of his family from Latvia]. (2018) RIA Novosti, November 16. [online] Available at: https://ria.ru/culture/20181116/1532948285. html [archived in WaybackMachine] (accessed 07.08.2019). (In Russ.).

Rezchikov, A. (2007) Geroev nazvali maroderami [Heroes were called looters]. Vzgliad, April 25. [online] Available at: https://vz.ru/politics/2007/4/25/79 260.html [archived in WaybackMachine] (accessed 04.08.2019). (In Russ.).

Sokolova, V. (2000) Delo Kononova slushaiut vnov' [Kononov's case is heard again]. Nezavisimoe voennoe obozrenie, April 14. [online] Available at: http://nvo.ng.ru/world/2000-04-14/1_kononov.html [archived in WaybackMachine] (accessed 18.06.2019). (In Russ.).

Starikov, N. V. (2011) Khaos i revoliutsii - oruzhie dollara [Chaos and revolutions - weapon of dollar]. St. Petersburg : Piter Publ. 330 p. (In Russ.).

Starikov, N. V. (2014) Geopolitika: kak eto delaetsia [Geopolitics: How it is pursued]. St. Petersburg : Piter Publ. 368 p. (In Russ.).

Starikov, N. V. (2016) Vlast' [Power]. St. Petersburg : Piter Publ. 320 p. (In Russ.).

Starikov, N. V. (2017) Voina: chuzhimi rukami [War: By proxy]. Moscow : Iauza Publ ; Eksmo Publ. 352 p. (In Russ.).

Starikov, N. V. (2018) Nenavist'. Khroniki rusofobii [Hatred. Chronicles of Russophobia]. St. Petersburg : Piter Publ. 352 p. (In Russ.).

Strakh i trepet: Mikser poprosil SShA usilit' «sderzhivanie» Rossii [Fear and awe: Mikser asked the USA to strengthen the "containment" of Russia]. (2018) Sputnik, March 7. [online] Available at: https://ru.sputnik-news.ee/estonian_ news/20180307/9628620/Mikser-poprosil-usa-usilitj-sderzhivanije-russia.html [archived in WaybackMachine] (accessed 28.07.2019). (In Russ.). 
Tarasov, A. N. (2002) Otkroveniia byvshego intelligenta [Revelations of a former member of the intelligentsia]. Svobodnaia mysl' - XXI, no. 2, pp. 64-69. (In Russ.).

Tarasov, A. N. (2003) O molodezhi — v zhanre donosa [On the youth - in the genre of denunciation]. Svobodnaia mysl' $-X X I$, no. 3, pp. 65-85. [online] Available at: http://scepsis.net/library/id_118.html [archived in WaybackMachine] (accessed 03.09.2018). (In Russ.).

Tarasov, A. N. (s/d) Fashizm v ideologii, ezhovshchina na praktike [Fascism in ideology, Ezhovshchina in practice]. $K$ novoi ideologii $-k$ novoi revoliutsii! [Towards a new ideology - towards a new revolution!] [online] Available at: http://saint-juste.narod.ru/aksionov.htm [archived in WaybackMachine] (accessed 05.09.2018). (In Russ.).

Fursov, A. I. (2007) Russkii kovcheg [Russian ark]. Zavtra, January 30. [online] Available at: http://zavtra.ru/blogs/2007-01-3151 [archived in WaybackMachine] (accessed 02.05.2019). (In Russ.).

Fursov, A. I. (2013) «Normal'naia nauka» versus «analitika» ["Normal science” versus “analytics”]. Svobodnaia mysl', no. 2 (1638), pp. 8-24. (In Russ.).

Tsygankov, A. P. (2015) Rusofobiia: antirossiiskoe lobbi $v$ SShA [Russophobia: Anti-Russian lobby in the USA]. Moscow : Eksmo Publ. 448 s. (In Russ.).

Estoniia otkryla dveri kazarm dlia transgenderov iz SShA [Estonia has opened the doors of barracks for transgender people from the USA]. (2018) Sputnik, March 6. [online] Available at: https://ru.sputnik-news.ee/world_news/2018 0306/9607055/Boevyje-transgendery-usa-armija-estonia.html [archived in WaybackMachine] (accessed 03.07.2019). (In Russ.).

Submission date: 02.09.2019.

Ильин Алексей Николаевич - кандидат философских наук, доцент кафедры практической психологии Омского государственного педагогического университета. Адрес: 644043, Россия, г. Омск, ул. Партизанская 4а, ауд. 117. Эл. адрес: $\underline{\text { ilin1983@yandex.ru. Сайт автора: http://ilinalexey.ru }}$

Ilyin Alexey Nikolaevich, Candidate of Philosophy, Associate Professor, Department of Practical Psychology, Omsk State Pedagogical University. Postal address: R. 117, 4a Partizanskaya Str., 644043 Omsk, Russian Federation. E-mail: ilin1983@yandex.ru. Website: http://ilinalexey.ru 
Для цитирования:

Ильин А. Н. Русофобия в Прибалтике [Электронный ресурс] // Горизонты гуманитарного знания. 2019. № 5. C. 14-46. URL: http://journals.mosgu.ru/ ggz/article/view/1101 (дата обращения: дд.мм.гггг). DOI: 10.17805/ggz.2019.5.2 